\title{
Interferon- $\gamma$ and Smac mimetics synergize to induce apoptosis of lung cancer cells in a TNFa-independent manner
}

\author{
Qin Hao and Hua Tang ${ }^{*}$
}

\begin{abstract}
Background: The prognosis of lung cancer is very poor and hence new therapeutic strategies are urgently desired. In this study, we searched for efficacious Smac mimetic-based combination therapies with biomarkers to predict responses for non-small cell lung cancer (NSCLC).

Methods: NSCLC cell lines and normal human alveolar epithelial cells were treated with Smac mimetics plus IFNy or other agonists and cell viabilities were assessed by MTS assay, cell counting, flow cytometry and cell colony assay. Western blot analysis was performed to assess the cleavage (activation) of caspases and expression of signaling molecules. Caspase activity was determined to verify caspase activation. The pathways involved in NSCLC cell death were investigated using specific inhibitors.

Results: We found that IFNY could cooperate with various Smac mimetics to trigger a profound apoptosis in a number of NSCLC cell lines that are competent for IFNy signaling (i.e. expressing IFNy receptor-1 and STAT1) but have low expression levels of inhibitor of apoptosis proteins survivin and livin without harming normal human lung epithelial cells. IFNy co-treatment with a novel class dimeric Smac mimetic AZD5582 eradicated NSCLC cell colony formation. Unlike IFNy, IFNa, IFN , TNFa, or TRAIL alone or plus AZD5582 had minor effects on NSCLC cell viability. IFNy/AZD5582induced cell death in NSCLC cells was independent of TNFa autocrine but relied on apoptosis mediated by JAK kinase, caspase 8 and RIPK1 pathways.

Conclusion: Our results indicate that IFNY and Smac mimetics can synergize to induce apoptosis of NSCLC cells and suggest that IFNy and Smac mimetic regimen may be a novel and efficacious apoptosis targeted therapy with biomarkers to predict responses for NSCLC cells.
\end{abstract}

Keywords: IFNy, Smac mimetic, Lung cancer, Apoptosis, Inhibitor of apoptosis

\section{Background}

Lung cancer is the leading cause of cancer mortality worldwide and contributes to about $30 \%$ of all cancer deaths [1]. Lung cancer can be divided into non-small cell lung cancer (NSCLC) which comprises $80-85 \%$ of total lung cancer cases, and the small cell lung cancer (SCLC) for the remaining $15-20 \%$ cases [2]. Attempts have been made to develop effective therapeutic strategies to

\footnotetext{
*Correspondence: hua.tang@uthct.edu

Department of Cellular and Molecular Biology, The University of Texas Health Science Center at Tyler, 11937 US Highway 271, Tyler, TX 75708, USA
}

combat lung cancer, such as the identification of mutations in epidermal growth factor receptor (EGFR), K-Ras, and p53, and the EGFR-targeted therapy; however over 5 years prognosis is about 16\% in NSCLC and ever lower for SCLC [3]. Lung cancer therefore represents a significant clinical challenge, clearly new therapeutic strategies are urgently needed.

Resistance to apoptosis is a hallmark of many solid tumors, including lung cancer. Thus, targeting apoptotic pathway represents a promising approach that aims to selectively kill cancer cells while sparing normal ones. Apoptosis, a programmed cell death in which dying cells are phagocytized prior to membrane damage, is a 
physiological and non-inflammatory process that differs from necroptosis [4]. Apoptosis is tightly regulated by inhibitor of apoptosis (IAP) proteins, a family of anti-apoptotic proteins that are highly expressed in various human cancers [5]. The function of IAP proteins is antagonized by second mitochondria-derived activator of caspases (Smac) that is released from mitochondria into the cytosol during apoptosis [6]. This led to the development of a series of small molecule Smac mimetics that neutralize X-linked IAP (XIAP), cellular IAP1 (cIAP1) and cIAP2 to enhance cancer cell susceptibility to apoptosis [5]. It has been shown that Smac mimetic sensitizes NSCLC cells to multiple chemotherapy agents in an IAP-dependent but tumor necrosis factor- $\alpha$ (TNF $\alpha$ )independent manner [7]. This finding is further confirmed by recent studies using different Smac mimetics in NSCLC $[8,9]$. IAP-targeted therapies in lung cancer by using Smac mimetics, antisense oligonucleotides and gene expression inhibitors have been evaluated in clinical phase I/II trials [10-12]. Other apoptosis targeted therapies in lung cancer, including therapies targeting TNFrelated apoptosis-inducing ligand (TRAIL) receptor and Bcl-2, have also gone through evaluation in preclinical and clinical phase I/II trials [10]. Although the efficacy of monotherapy appears to be limited, the apoptotic drugs seem to be promising especially in combination with other traditional therapies [10]. However, these studies lack of identification of lung cancer patient subgroups who will most likely benefit from specific apoptosis targeted therapies. Biomarkers that can predict responses to apoptosis targeted agents are important and remain to be identified.

In this study, we searched for efficacious Smac mimetic-based combination therapies with biomarkers to predict responses for lung cancer. We show that a number of human NSCLC cell lines that are competent for interferon- $\gamma$ (IFN $\gamma$ ) signaling (i.e. expressing IFN $\gamma$ receptor-1 and STAT1) but have low expression levels of IAP proteins survivin and livin, can be readily killed through apoptosis by IFN $\gamma$ and Smac mimetic co-treatment without harming normal human lung epithelial cells.

\section{Methods}

\section{Smac mimetics and reagents}

The Smac mimetic AZD5582 was obtained from Chemietek (Indianapolis, IN, USA) and Smac mimetics SM164, BV6, and Birinapant (TL32711) were from APExBIO (Houston, TX, USA). Recombinant human IFN $\alpha$ was from PBL Assay Science (Piscataway, NJ, USA) and IFN $\gamma$, IFN $\lambda$, TNF $\alpha$, and Annexin V-FITC were from eBioscience (San Diego, CA, USA). Recombinant human TRAIL was from ProSpec TechnoGene (East Brunswick NJ, USA). Polyinosinic-polycytidylic acid (poly(I:C)) was from InvivoGen (San Diego, CA, USA). Necrostatin-1, necrosulfonamide, GSK872, Bay11-7082, JAK kinase inhibitor I, AG-1478, and cisplatin were from EMD Millipore (Billerica, MA, USA). The general caspase peptide inhibitor Z-VAD-FMK and the caspase-8 peptide inhibitor Z-IETD-FMK were from $\mathrm{R} \& \mathrm{D}$ Systems (Minneapolis, MN, USA). Human TNF $\alpha$ neutralizing antibody (\#7321) was from Cell Signaling Technology (Beverly, MA, USA). Caspase- 3 and -8 colorimetric assay kits were from BioVision (Milpitas, CA, USA). All other chemicals were obtained from Sigma-Aldrich (St. Louis, MO, USA).

\section{Cell culture and cell viability assay}

Human NSCLC cell lines including NCI-H1975, NCI-H1437, NCI-H441, HCC827, A549, and Calu-3 were obtained from American Type Culture Collection (Manassas, VA, USA) and cultured in RPMI-1640 medium supplemented with $10 \%$ fetal calf serum. Primary normal human alveolar epithelial cells were from Cell Biologics (Chicago, IL, USA), cultured in epithelial cell growth medium, and used for experiments within four passages. For cell viability assay, cells were seeded into 48-well plates, grown to subconfluence, then incubated with various agonists in the presence or absence of Smac mimetics, caspase or kinases inhibitors for indicated time periods. Cell viability was assessed by MTS assay using CellTiter $\mathrm{AQ}_{\text {ueous }}$ one solution reagent according to the manufacturer's instructions (Promega, Madison, WI, USA) and cell counting with trypan blue by a TC20 automated cell counter. Cell survival rate was calculated by comparison to DMSO-treated control cells and are presented as mean $\pm \operatorname{SE}(n=3)$.

\section{Cell colony assay}

Cells were seeded into 12 -well plates at 500 cells/well overnight and then incubated with different agonists in the presence of control DMSO or Smac mimetics for 4 weeks. Media were changed every 5 days. Cell colonies were fixed and stained with $0.05 \%$ crystal violet and the stain was eluted and quantified at $540 \mathrm{~nm}$.

\section{Western blot analysis}

Western blot analysis was performed essentially as we described previously [13]. The membranes were probed with the following primary antibodies against: phosphoreceptor-interacting protein kinase-1 (RIPK1) (Ser166) (\#65746), cleaved caspase-3 (\#9664), -7 (\#8438), -8 (\#9496), -9 (\#7237), cleaved poly (ADP-ribose) polymerase (PARP) (\#9541), cIAP-1 (\#7065), cIAP-2 (\#3130), XIAP (\#2045), survivin (\#2808), livin (\#5471), STAT1 (\#9712), phospho-STAT1 (\#7649), STAT3 (\#9139), JAK1 (\#3332), JAK2 (\#3229) (Cell Signaling Technology, Beverly, MA, USA), IFN $\gamma$ receptor 1 (\#AF673) (R \& D 
Systems, Minneapolis, MN, USA), EGFR (\#sc-03) (Santa Cruz Biotechnology, Santa Cruz, CA, USA), vinculin (\#V9131) and actin (\#A4700) (Sigma. St. Louis, MO, USA). The membranes were then incubated with horseradish peroxidase-conjugated secondary antibodies (Cell Signaling Technology) and detected with Bio-Rad Clarity Western ECL substrate (Hercules, CA, USA).

\section{Annexin $V$ apoptosis assay}

Cells were seeded into 6-well plates, grown to subconfluence, then incubated with AZD5582 and IFNy for $48 \mathrm{~h}$. Floating dead cells were removed and the adherent cells were rinsed and harvested with a diluted trypsin solution. Cells were then stained with FITC Annexin V to identify cells undergoing apoptosis by flow cytometry.

\section{Caspase -3 and -8 activity assay}

Cell lysates $(100 \mu \mathrm{g})$ were incubated with $200 \mu \mathrm{M}$ of caspase-3 substrate DEVD-chromophore p-nitroaniline (pNA) or caspase- 8 substrate IETD-pNA in $2 \times$ reaction buffer, and pNA light emission was detected at $405 \mathrm{~nm}$ according to the manufacturer's protocol (BioVision) and presented as $\mathrm{OD}_{405 \mathrm{~nm}}$ over $500 \mu \mathrm{g}$ protein.

\section{Statistical analysis}

Data are expressed as mean \pm SE. Statistical analyses were performed using Microsoft Excel and GraphPad Prism (GraphPad Software, La Jolla, CA, USA). Data were analyzed by Student's $t$ test. $\mathrm{p}<0.05$ is considered statistically significant.

\section{Results}

IFNy cooperates with Smac mimetics to trigger a TNFa-independent apoptosis in the $\mathrm{H} 1975$ NSCLC cell line

As shown in Fig. 1a, we treated H1975 human NSCLC cell line harboring EGFR T790 $\mathrm{M}$ and L858R mutations with AZD5582 [14], a novel class of dimeric Smac mimetics, plus various agonists for $48 \mathrm{~h}$ and the cell viability was assessed. We found that AZD5582 alone at $20 \mathrm{nM}$ slightly inhibited cell viability, but it could cooperate with IFN $\gamma$ to profoundly induce cell death even with IFN $\gamma$ at $1 \mathrm{ng} / \mathrm{ml}$. In contrast, AZD5582 barely induced such synergetic effects with TNF $\alpha$, IFN $\alpha$, or IFN $\lambda$. As expected, IFN $\gamma$ alone reduced cell viability dose-dependently, which might be due to the direct inhibition of cell proliferation and induction of apoptosis [15]. Interestingly, AZD5582 also cooperated with poly(I:C), a synthetic analog of viral double-stranded RNA (dsRNA) to induce cell death, whereas AZD5582 had a minor effect on cell death by cisplatin or TRAIL (Fig. 1b). We further showed that IFN $\gamma$ or poly(I:C) not only cooperated with
AZD5582 but also with other Smac mimetics including SM164 [16], BV6 [17] and Birinapant [18] to markedly induce cell death, and that IFN $\gamma$ appeared to have a stronger effect compared with poly(I:C) (Fig. 1c-f). Birinapant is a monovalent Smac mimetic and its synergetic effect was weaker than other three bivalent Smac mimetics. Moreover, cell counting with trypan blue confirmed the synergetic effects on cell death induced by AZD5582 plus IFN $\gamma$ or poly(I:C) (Fig. 1g, h). Additionally, AZD5582 plus IFN $\gamma$ and poly(I:C) appeared to have a stronger effect on cell death than AZD5582 plus IFNy or AZD5582 plus poly(I:C) (Fig. 1g). To assess contribution of apoptosis to the cell death, we performed Western blots analysis and found that AZD5582 alone down-regulated cIAP-1 but not XIAP, activated RIPK1 [19] that is an important upstream regulator of caspase-8, and triggered the cleavage (activation) of extrinsic (caspase-8) and intrinsic (caspase-9) apoptosis pathways, causing the cleavage (activation) of caspase-3 and caspase-7, the primary executioners of apoptosis, and of DNA repair enzyme PARP, one of the main cleavage targets of caspase-3 (Fig. 2). Importantly, the apoptosis-inducing effect of AZD5582 was markedly enhanced by co-treatment with IFN $\gamma$ (Fig. 2). These findings suggest that IFNY and Smac mimetics synergistically kill H1975 NSCLC cells likely through apoptosis. To assess the long term effect on cell growth, we performed colony formation assay and found that no cell colony could survive by co-treatment of AZD5582 with IFN $\gamma$ at 1 or $5 \mathrm{ng} / \mathrm{ml}$ (Fig. 3). In contrast, a great number of colonies formed in medium containing AZD5582 alone or AZD5582 plus poly(I:C). IFNy alone or IFNy plus poly(I:C) markedly inhibited clonogenic growth, but could not eradicate the colony formation (Fig. 3).

We further examined the molecular basis of cell death by AZD5582 co-treatment with IFN $\gamma$ or poly(I:C) in $\mathrm{H} 1975$ cells. We found that AZD5582/IFN $\gamma$-induced cell death was almost blocked by a specific JAK kinase inhibitor [20] and markedly prevented by a general caspase inhibitor Z-VAD-FMK [21], a specific caspase-8 inhibitor Z-IETD-FMK [22] and a selective RIPK1 inhibitor necrostatin-1 [23] (Fig. 4a, b). While AZD5582/ poly(I:C)-induced cell death was markedly suppressed by Z-VAD-FMK and Z-IETD-FMK, partially suppressed by the specific JAK kinase inhibitor, but was not affected by necrostatin-1 (Fig. 4a, b). Moreover, cell death induced by AZD5582 plus IFNY or poly(I:C) was essentially not affected by a NK-KB inhibitor BAY11-7082, an EGFR inhibitor AG1478, a human TNFo neutralizing antibody, a specific inhibitor (GSK872) of necroptosis initiator RIPK3 [24], or a specific inhibitor (necrosulfonamide) of necroptosis effector mixed lineage kinase domain-like 

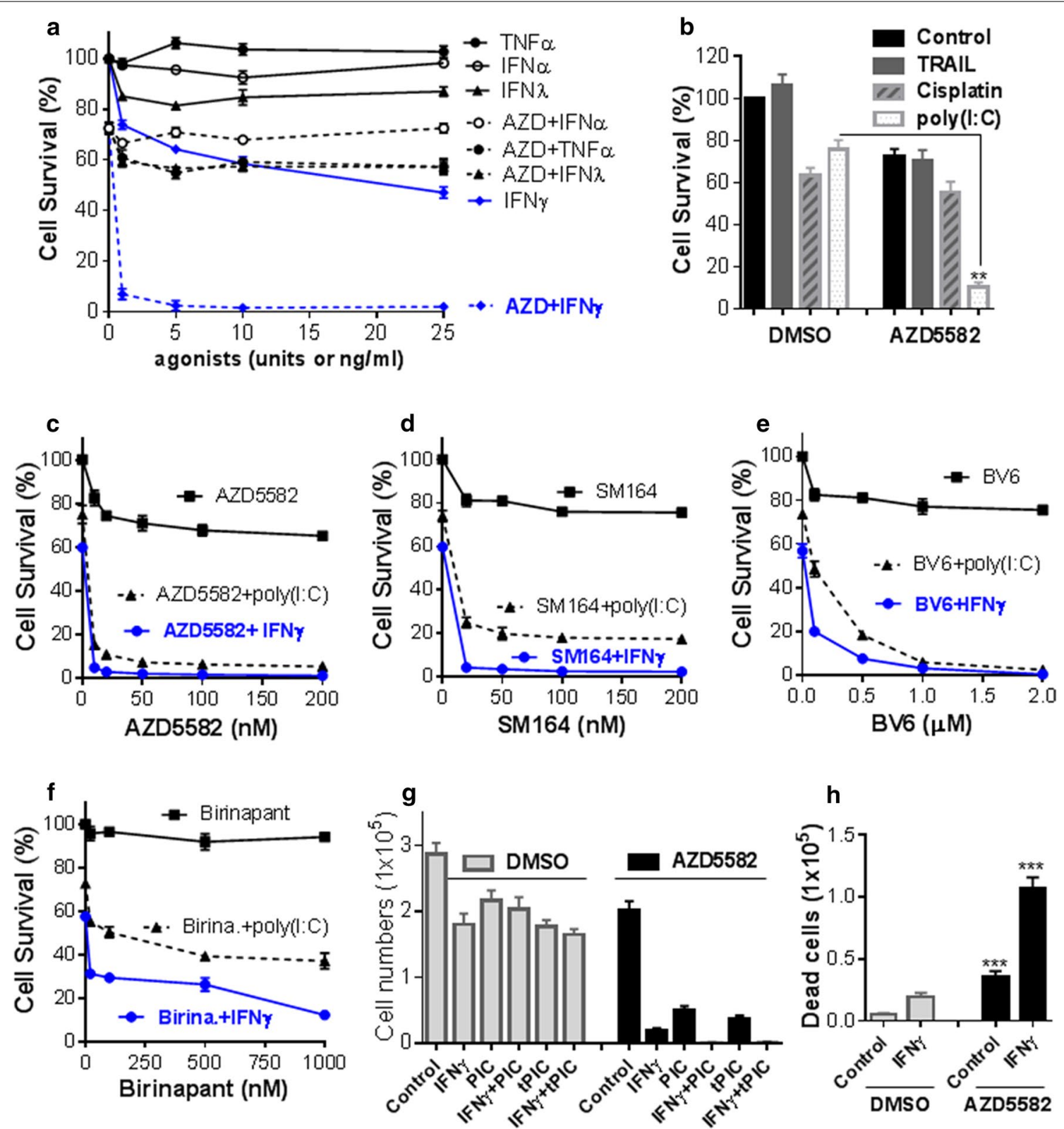

Fig. 1 IFNY and Smac mimetics synergistically induce cell death in the H1975 NSCLC cell line. a, b H1975 NSCLC cells were incubated with 1-25 units of human IFNa or $1-25 \mathrm{ng} / \mathrm{ml}$ of IFNy, IFN $\lambda$ or TNFa, TRAIL $(500 \mathrm{ng} / \mathrm{ml})$, cisplatin $(25 \mu \mathrm{M})$ or poly $(\mathrm{l}: \mathrm{C})(500 \mathrm{ng} / \mathrm{ml})$ in the presence or absence of $20 \mathrm{nM}$ AZD5582 for 48 h. c-f H1975 cells were incubated with $10 \mathrm{ng} / \mathrm{ml} \mathrm{IFNy} \mathrm{or} 250 \mathrm{ng} / \mathrm{ml}$ poly(l:C) plus different doses of AZD5582 (c), SM164 (d), BV6 (e) or Birinapant (f) for $48 \mathrm{~h}$. Cell viabilities (a-f) were assessed by MTS assay and cell survival rates were calculated by comparison to DMSO-treated control cells and are presented as mean \pm SE $(n=3) . \mathbf{g ~ H} 1975$ cells were treated with IFNy $(10 \mathrm{ng} / \mathrm{ml}), \mathrm{poly}(\mathrm{l}: \mathrm{C})(\mathrm{PIC}, 500 \mathrm{ng} / \mathrm{ml})$, IFNy plus poly(l:C), or transfected with poly(l:C) (tPIC, $100 \mathrm{ng} / \mathrm{ml})$ alone or plus IFNy in the presence or absence of $20 \mathrm{nM}$ AZD5582 for $48 \mathrm{~h}$. Viable cells were counted with trypan blue by a TC20 automated cell counter $(\mathrm{n}=3)$. $\mathbf{h} \mathrm{H} 1975$ cells were treated with IFNy $(5 \mathrm{ng} / \mathrm{ml})$ in the presence of DMSO or AZD5582 (20 nM) for $48 \mathrm{~h}$, and the detached cells were collected and counted with trypan blue by a TC20 automated cell counter $(\mathrm{n}=3)$. ${ }^{* *} p<0.01 ;{ }^{* *} p<0.001$ versus DMSO. Results represent the findings of three independent experiments

protein (MLKL) [25] (Fig. 4b, c). These findings indicate that AZD5582/IFN $\gamma$-induced cell death in H1975 NSCLC cell line is mediated by JAK kinase through apoptosis pathway independent of TNFa autocrine and necrotic cell death (necroptosis).
IFN $\gamma$ and Smac mimetics synergistically induce apoptosis in IFN $\gamma$ signaling competent NSCLC cell lines

Similar to the H1975 cell line, we found that Smac mimetics AZD5582 or SM164 cooperated with IFN $\gamma$,

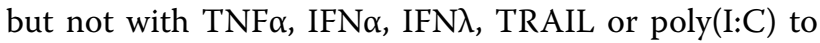




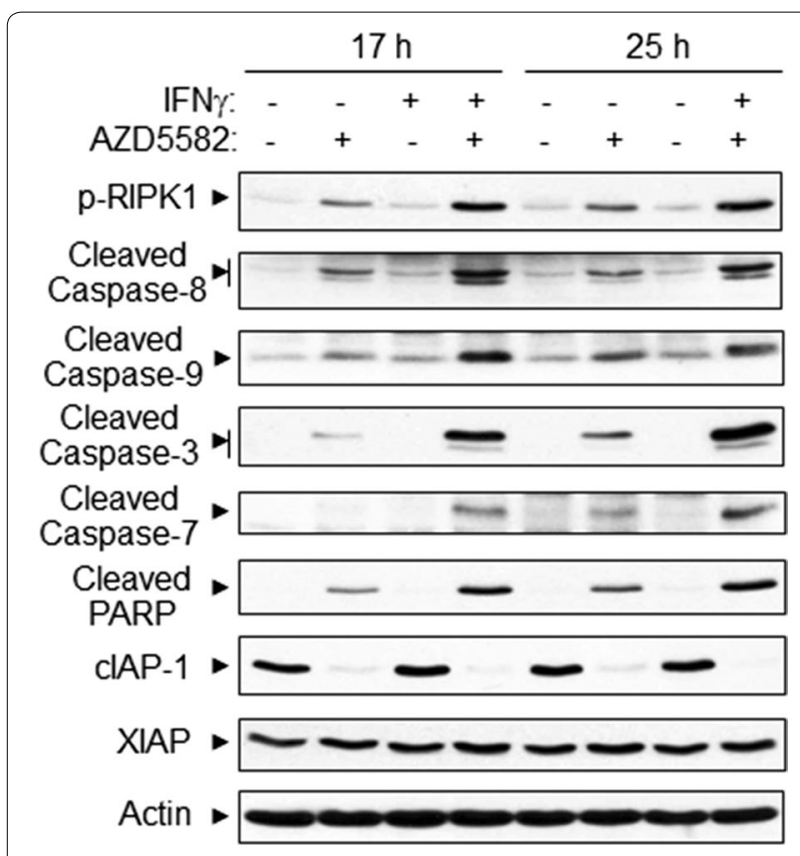

Fig. 2 IFNY and Smac mimetic AZD5582 synergistically induce caspase activation in H1975 NSCLC cell line. H1975 cells were treated with IFNy (10 ng/ml) and AZD5582 (20 nM) for 17 or $25 \mathrm{~h}$, and cell lysates at equal amounts were subjected to Western blotting with indicated antibodies. Results represent Western blots of three independent experiments

induce cell death in HCC827 NSCLC cell line overexpressing EGFR and harboring L858R mutation (Fig. 5ae). It should be noted that Smac mimetics AZD5582 and SM164 alone or AZD5582 plus poly(I:C) barely had effects on cell viability in HCC827 cells (Fig. 5c-e), which is different from the observation in H1975 cells. Majority of HCC827 cells were killed by co-treatment of AZD5582 $(20 \mathrm{nM})$ plus IFN $\gamma(5 \mathrm{ng} / \mathrm{ml})$ for $48 \mathrm{~h}$, resulting in a large amount of detached dead cells. The remaining adherent cells were subjected to Annexin V apoptosis assay; and we found that $26.4 \%$ of cell populations were detected with a higher Annexin $\mathrm{V}$ binding, indicating cells undergoing apoptosis (Fig. 5e, right panel). We further found that AZD5582 and IFNY synergistically induced a timedependent cleavage (activation) of caspase- 8 and PARP in HCC827 cells (Fig. 5f). We also measured caspase-3 and -8 activities using specific peptide substrates and found that both caspases were markedly activated by AZD5582 and IFN $\gamma$ co-treatment in HCC827 cells (Fig. 5g, h). Moreover, we found that AZD5582/IFNYinduced cell death in HCC827 cells was markedly suppressed by a general caspase inhibitor Z-VAD-FMK [21] and a selective RIPK1 inhibitor necrostatin-1 [23], indicating the involvement of apoptosis (Fig. 5i). In contrast, the AZD5582/IFN $\gamma$-induced cell death was essentially not affected by a human TNF $\alpha$ neutralizing antibody, the RIPK3 inhibitor GSK872 [24], MLKL inhibitor necrosulfonamide [25], or a selective caspase-1 inhibitor VX-765 [26].

The synergetic effects of IFN $\gamma$ with Smac mimetics AZD5582, SM164 or BV6 on cell death was also observed in NSCLC cell line H1437 harboring p53 mutation; however Smac mimetics alone or AZD5582 plus poly(I:C) had only a minor effect on the cell viability (Fig. 6a-c). Western blots analysis revealed that AZD5582 and IFNY synergistically and markedly induced the cleavage (activation) of caspase-8 and PARP in H1437 cells (Fig. 6d). In A549 cells, AZD5582 alone had a minor effect on cell
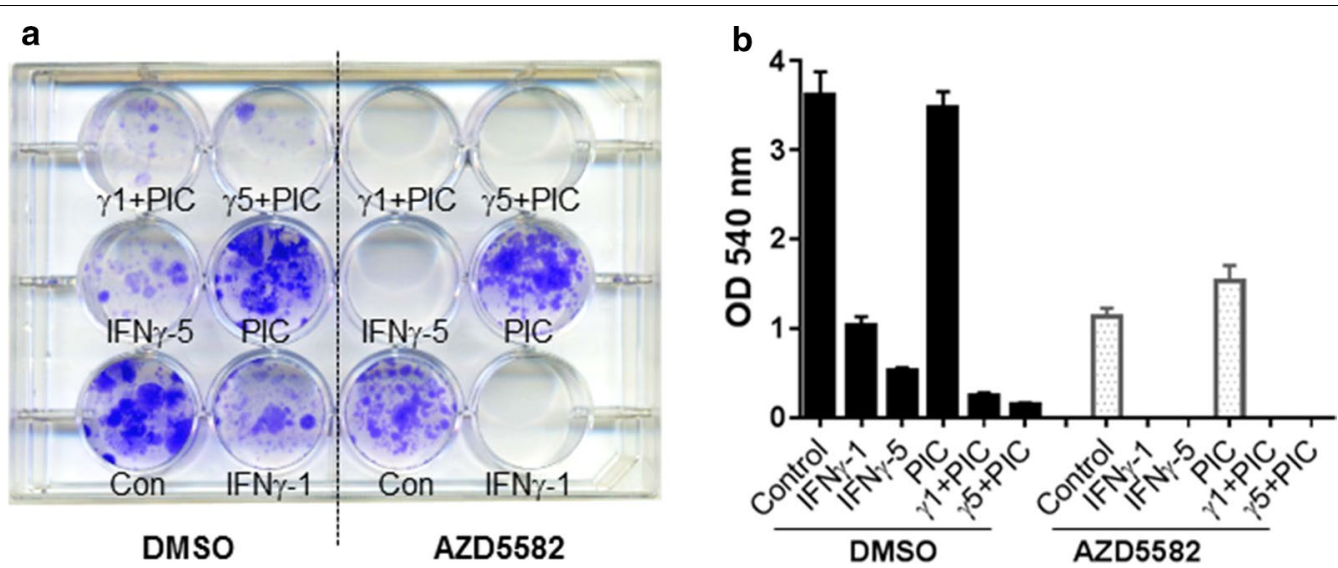

Fig. 3 No H1975 cell colony survives by co-treatment of IFNy with Smac mimetic AZD5582. H1975 cells were incubated with 1 or 5 ng/ml IFNy (IFNy-1 or IFNy-5), poly(l:C) (PIC, $250 \mathrm{ng} / \mathrm{ml})$, or poly(l:C) $(250 \mathrm{ng} / \mathrm{ml})$ with 1 or $5 \mathrm{ng} / \mathrm{ml}$ IFNy ( 1 + PIC or $\gamma 5+$ PIC) in the presence of control DMSO or AZD5582 (20 nM) for 4 weeks. Cell colonies were stained with crystal violet shown in plate (a) and crystal violet stain was eluted and quantified at OD540 $\mathrm{nm}$ (b). Results represent three independent experiments 


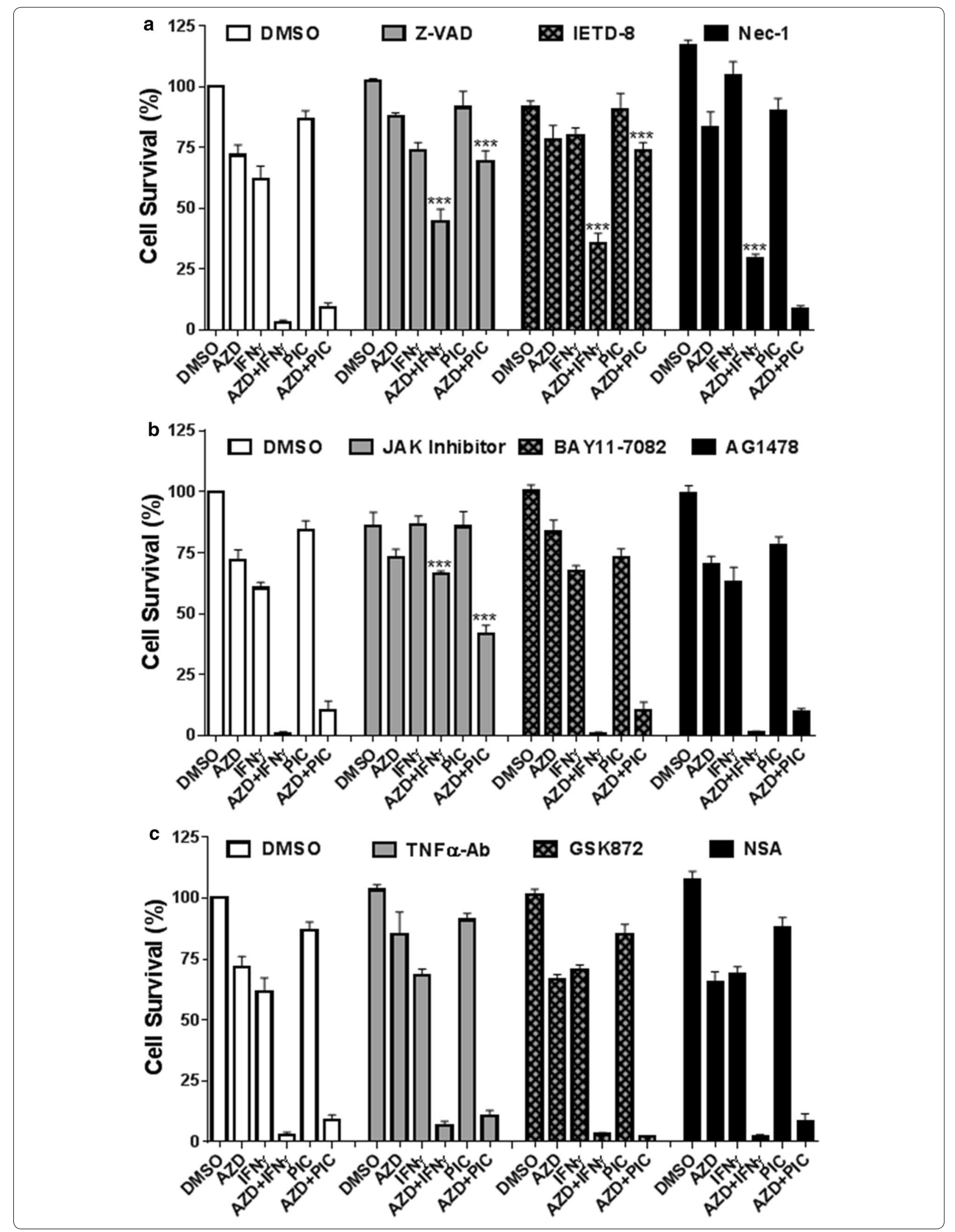


(See figure on previous page.)

Fig. 4 IFNY/AZD5582-induced apoptosis is mediated by JAK kinase but not TNFa production in H1975 NSCLC cell line. H1975 cells were incubated with DMSO, AZD5582 (20 nM), IFNy (10 ng/ml), poly(l:C) (PIC, $250 \mathrm{ng} / \mathrm{ml})$, AZD5582 plus IFNy (AZD + IFNy), or AZD5582 plus poly(l:C) (AZD + PIC)

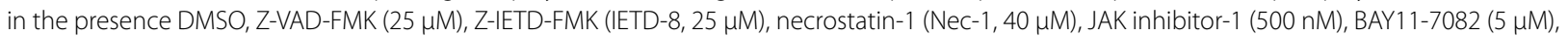
AG1478 (250 nM), TNFa neutralizing antibody (TNFaAb, $1 \mu \mathrm{g} / \mathrm{ml})$, GSK872 $(5 \mu \mathrm{M})$, necrosulfonamide (NSA, $1 \mu \mathrm{M})$ for $48 \mathrm{~h}$. Cell viabilities were assessed by MTS assay and cell survival rates were calculated by comparison to DMSO-treated control cells $(n=3)$. ${ }^{* *} p<0.001$ versus DMSO. Results represent the findings of three independent experiments

viability; however it could cooperate with IFN $\gamma$ to induce cell death even though the magnitude was much lower compared with H1975, HCC827 and H1437 cell lines (Fig. 6e). On the contrary, Smac mimetics alone or plus IFN $\gamma$ or poly(I:C) essentially did not trigger cell death in NSCLC cell lines Calu-3 and H441 and in primary normal human alveolar epithelial cells (HAECs) (Fig. 6f-h).

Western blot analysis shows that NSCLC cell lines $\mathrm{H} 441$ and Calu-3 which were resistant to IFN $\gamma / \mathrm{Smac}$ mimetic co-treatment did not express STAT1 [27], a central molecular for IFNY signaling (Fig. 7a, second panel). A549 cells that weakly responded to IFN $\gamma / \mathrm{Smac}$ mimetic co-treatment expressed STAT1 but had less phosphorylation of STAT1 on Tyr-701 compared with H1975, HCC827 and H1437 cell lines (Fig. 7a, first panel). Moreover, among the examined IAP proteins, survivin and livin were highly expressed in A549 cells (Fig. 7b, first and second panels). Survivin was also highly expressed in H441 and Calu-3 cells. All the examined NSCLC cell lines expressed IFN $\gamma$ receptor-1, JAK1/2, STAT3 and comparable levels of cIAP-1 and XIAP (Fig. 7). In addition, primary HAECs expressed IFN $\gamma$-R1, STAT1 and JAK1/2 (data not shown). Taken together, our findings indicate that Smac mimetics and IFN $\gamma$ synergistically induce apoptosis only in IFN $\gamma$ signaling competent NSCLC cell lines. It also suggests that high expression levels of survivin and livin in A549 cells may render the cell not very responsive to IFN $\gamma / \mathrm{Smac}$ mimetic regimen.

\section{Discussion}

Lung cancer represents a significant clinical challenge; hence new therapeutic strategies are urgently needed. In the present study, we report a novel finding that IFN $\gamma$ cooperates with Smac mimetics to trigger a profound apoptosis in a number of human NSCLC cell lines that are competent for IFN $\gamma$ signaling (i.e. expressing IFN $\gamma$ receptor-1 and STAT1) but have low expression levels of IAP proteins survivin and livin without harming normal lung epithelial cells. We further show that IFNY/AZD5582-induced cell death in NSCLC cell lines is mediated by JAK kinase through apoptosis but not necroptosis pathway independent of TNF $\alpha$ autocrine. Thus, IFN $\gamma$ and Smac mimetic regimen may be a novel and efficacious apoptosis targeted therapy with biomarkers to predict responses for NSCLC cells.

Smac mimetics as mono- or combination therapies are currently undergoing clinical evaluation in many trials against a variety of human cancers $[11,12]$. Smac mimetics when tested as single agents can induce apoptosis in cancer cells via a TNF $\alpha$ autocrine mechanism $[28,29]$, but only a small subset of cancer cells response to Smac mimetics and there is no biomarker to predict the response. AZD5582 is a novel class of dimeric Smac mimetics and its antiproliferative effect is only observed in 14 out of 200 examined cancer cell lines, consistent with other published IAP inhibitors [14]. Similarly, we found that Smac mimetics such as AZD5582, SM164 or BV6 alone only slightly (20-30\%) inhibited cell viability in H1975 and H1437 cells but essentially had no effect in other 4 NSCLC cell lines. Although the efficacy of monotherapy appears to be limited, Smac mimetic-based combination anticancer therapies seem to be promising $[11,12]$. It has been shown that Smac mimetic sensitizes NSCLC cells to multiple chemotherapy agents in a TNF $\alpha$-independent manner [7], which is further confirmed by recent studies

\footnotetext{
(See figure on next page.)

Fig. 5 IFNY and Smac mimetics synergistically induce apoptosis in HCC827 NSCLC cell line. a, b HCC827 NSCLC cells were incubated with 1-25 units of human IFNa or $1-25 \mathrm{ng} / \mathrm{ml}$ of IFNy, IFN or TNFa (a), or with TRAIL (200 or $400 \mathrm{ng} / \mathrm{ml}$ ) (b) in the presence or absence of $20 \mathrm{nM} \mathrm{AZD5582} \mathrm{for}$ $48 \mathrm{~h} . \mathbf{c ~ H C C 8} 27$ cells were incubated with various doses of poly $(\mathrm{l}: \mathrm{C})$ in the presence or absence of $20 \mathrm{nM}$ AZD5582 for $48 \mathrm{~h}$. d, e HCC 827 cells were incubated with $5 \mathrm{ng} / \mathrm{ml} \mathrm{IFNy}$ plus different doses of SM164 or AZD5582 for $48 \mathrm{~h}$. The remaining adherent cells after $48 \mathrm{~h}$ treatment with AZD5582 ( $20 \mathrm{nM}$ ) plus IFNy $(5 \mathrm{ng} / \mathrm{ml}$ ) were subjected to Annexin V apoptosis assay (e). $\mathbf{f}$ HCC827 cells were treated with IFNy (5 ng/ml) and AZD5582 (20 nM) for 7 or 26 h, and cell lysates at equal amounts were subjected to Western blotting with indicated antibodies. $\mathbf{g}, \mathbf{h}$ HCC 827 cells were treated with IFNY $(5 \mathrm{ng} / \mathrm{ml})$ and AZD5582 (20 nM) for $24 \mathrm{~h}$ and caspase- 8 and -3 activities were determined. $\mathbf{i}$ HCC 827 cells were incubated with DMSO,

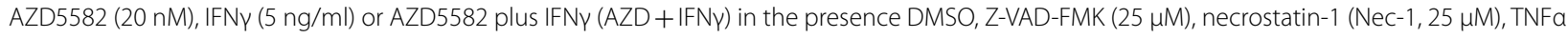
neutralizing antibody (TNFaAb, $1 \mu \mathrm{g} / \mathrm{ml}$ ), GSK872 (GSK, $5 \mu \mathrm{M}$ ), necrosulfonamide (NSA, $1 \mu \mathrm{M})$, or VX-765 (10 $\mu \mathrm{M})$ for $48 \mathrm{~h}$. Cell viabilities (a-e, i) were assessed by MTS assay and cell survival rates were calculated by comparison to DMSO-treated control cells $(n=3) .{ }^{* *} p<0.01$; ${ }^{* *} p<0.001$ versus DMSO. Results represent three independent experiments
} 


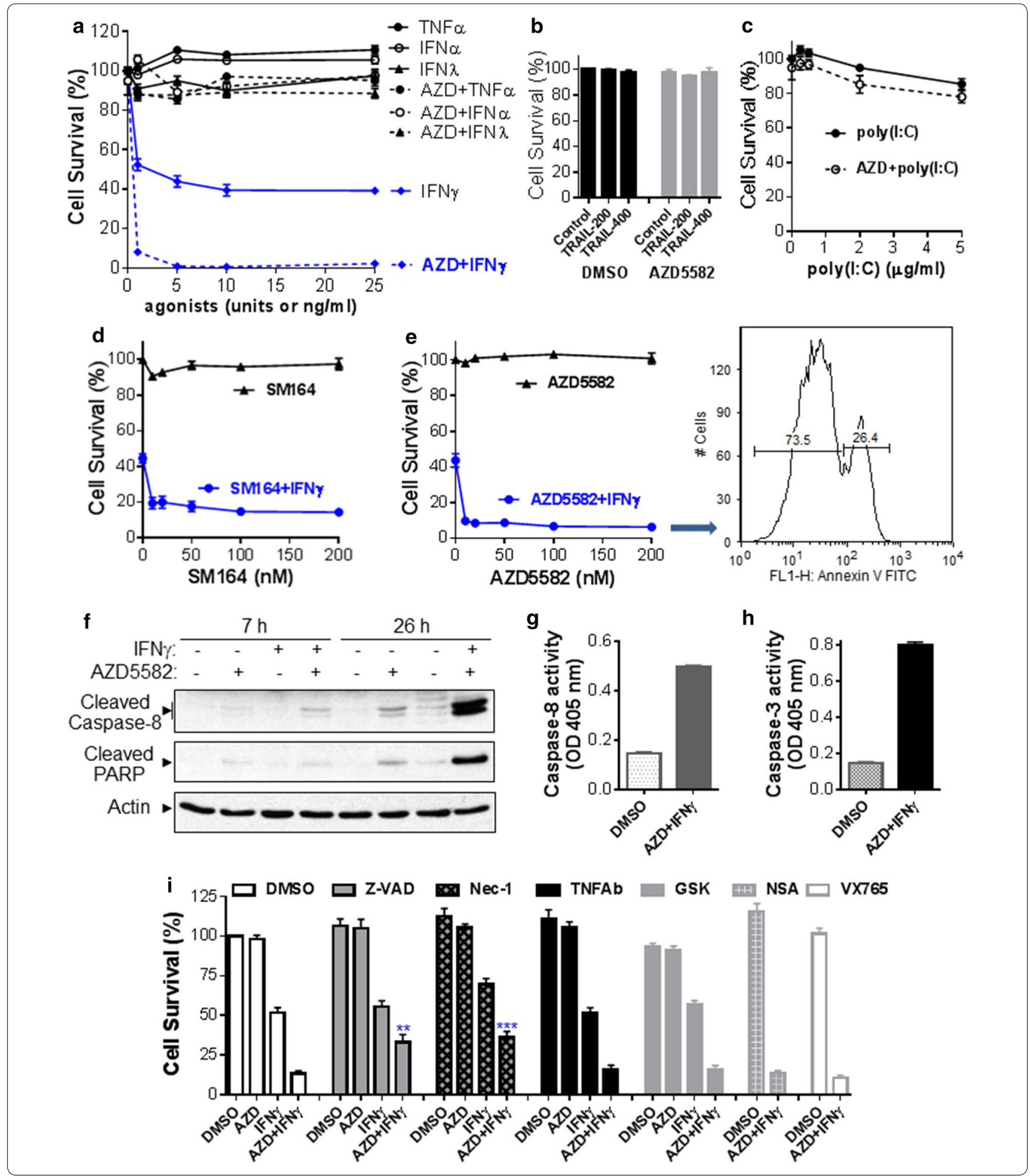

using different Smac mimetics in NSCLC $[8,9]$. However, these studies lack of identification of subgroups of lung cancer patients who will most likely benefit from IAP-targeted therapies. We found that Smac mimetics such as AZD5582, SM164 and BV6 could cooperate with IFNY to profoundly $(>90 \%)$ induce cell death in H1975, HCC827 and H1437 NSCLC cell lines that expressed STAT1 [27], a central molecular for IFN $\gamma$ signaling. A549 cells that weakly responded to IFN $\gamma /$ Smac mimetic co-treatment also expressed STAT1 but 


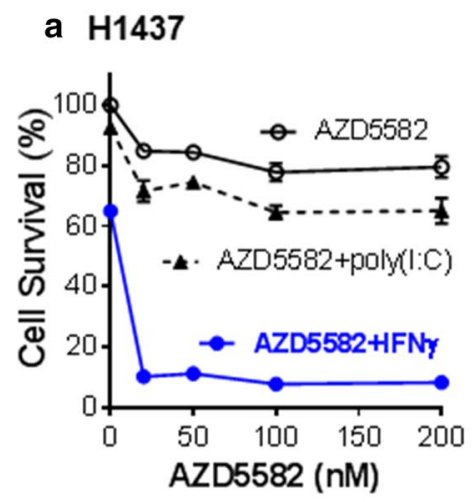

d $\mathrm{H} 1437$

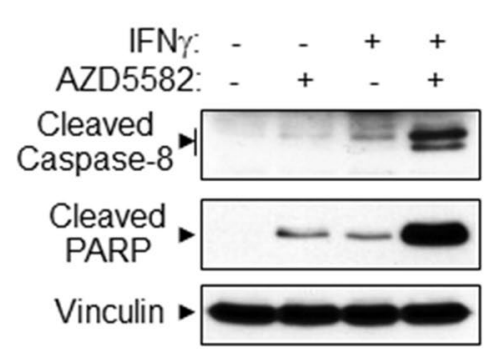

b $\mathrm{H} 1437$

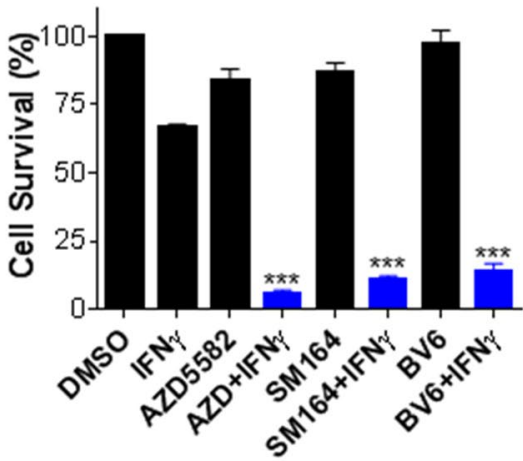

e $\mathbf{4 5 4 9}$

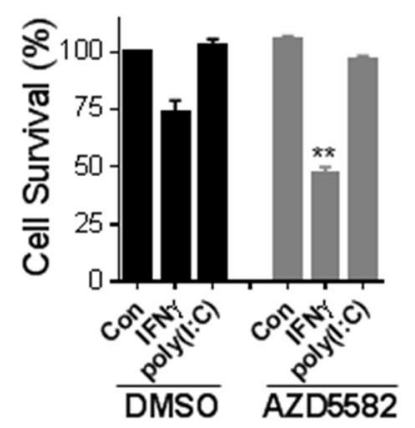

\section{c $\mathrm{H} 1437$}

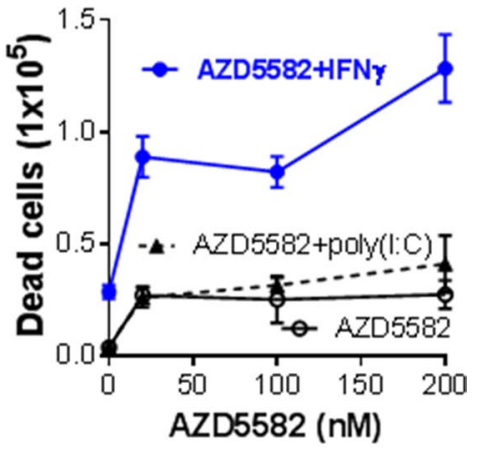

f Calu-3

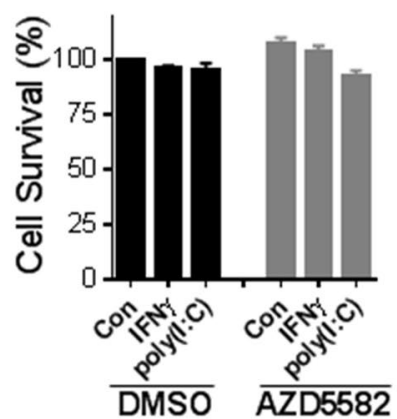

g $\mathrm{H} 441$

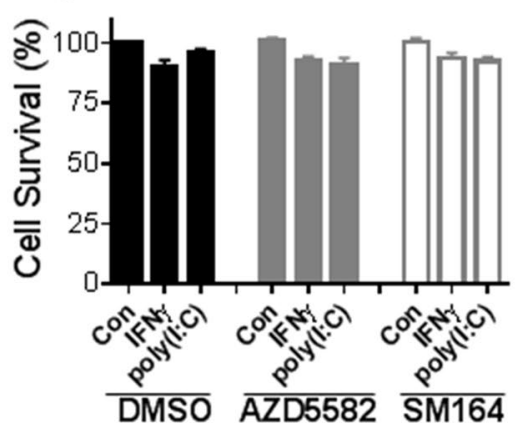

h HAEC

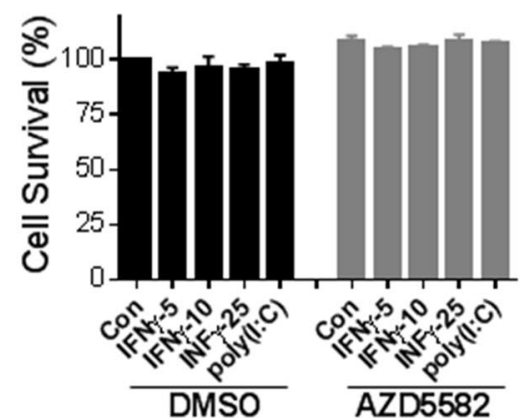

Fig. 6 Effects of IFNy and Smac mimetics on cell death in other NSCLC cells and HAECs. a, b H1437 cells were incubated with $10 \mathrm{ng} / \mathrm{ml}$ IFNy or $250 \mathrm{ng} / \mathrm{ml}$ poly(l:C) plus different doses of AZD5582 (a) or with $10 \mathrm{ng} / \mathrm{ml}$ IFNy alone or plus $20 \mathrm{nM}$ AZD5582, $20 \mathrm{nM}$ SM164, or $250 \mathrm{nM}$ BV6 (b) for $60 \mathrm{~h}$, and cell viabilities were assessed. c H1437 cells were treated with IFNy $(10 \mathrm{ng} / \mathrm{ml})$ or poly (l:C) (250 ng/ml) plus different doses of AZD5582 for $60 \mathrm{~h}$, and the detached cells were collected and counted with trypan blue by a TC20 automated cell counter $(n=3)$. $\mathbf{d}$ H1437 cells were treated with IFNy $(10 \mathrm{ng} / \mathrm{ml})$ and AZD5582 $(20 \mathrm{nM})$ for $27 \mathrm{~h}$, and cell lysates at equal amounts were subjected to Western blotting with indicated antibodies. e-h A549, Calu-3 and H441 NSCLC cell lines or HAECs were treated with IFNy ( $25 \mathrm{ng} / \mathrm{ml})$ or poly(l:C) $(250 \mathrm{ng} / \mathrm{ml})$ or with the indicated amounts of IFNY (h) in the presence of DMSO or $20 \mathrm{nM}$ of AZD5582 or SM164 for $72 \mathrm{~h}$. Cell viabilities (a-h) were assessed by MTS assay and cell survival rates were calculated by comparison to DMSO-treated control cells $(n=3) .{ }^{* *} p<0.01,{ }^{* * *} p<0.001$ versus DMSO. Results represent three independent experiments

had less STAT1 phosphorylation on Tyr-701 compared with H1975, HCC827 and H1437 cell lines. In contrast, NSCLC cell lines H441 and Calu-3 that did not express STAT1 were resistant to IFN $\gamma / \mathrm{Smac}$ mimetic co-treatment. All the 6 examined NSCLC cell lines expressed IFN $\gamma$ receptor-1, JAK1/2, STAT3 and comparable levels of cIAP-1 and XIAP. Thus our findings indicate that
Smac mimetics and IFNY synergistically induce apoptosis only in IFN $\gamma$ signaling competent (i.e. expressing IFNY receptor-1 and STAT1) NSCLC cell lines. It has been shown that STAT1 is one of five good genes closely associated with relapse-free and overall survival among NSCLC patients [30]. STAT1 may be a potential biomarker that can predict response to IFN $\gamma / \mathrm{Smac}$ 

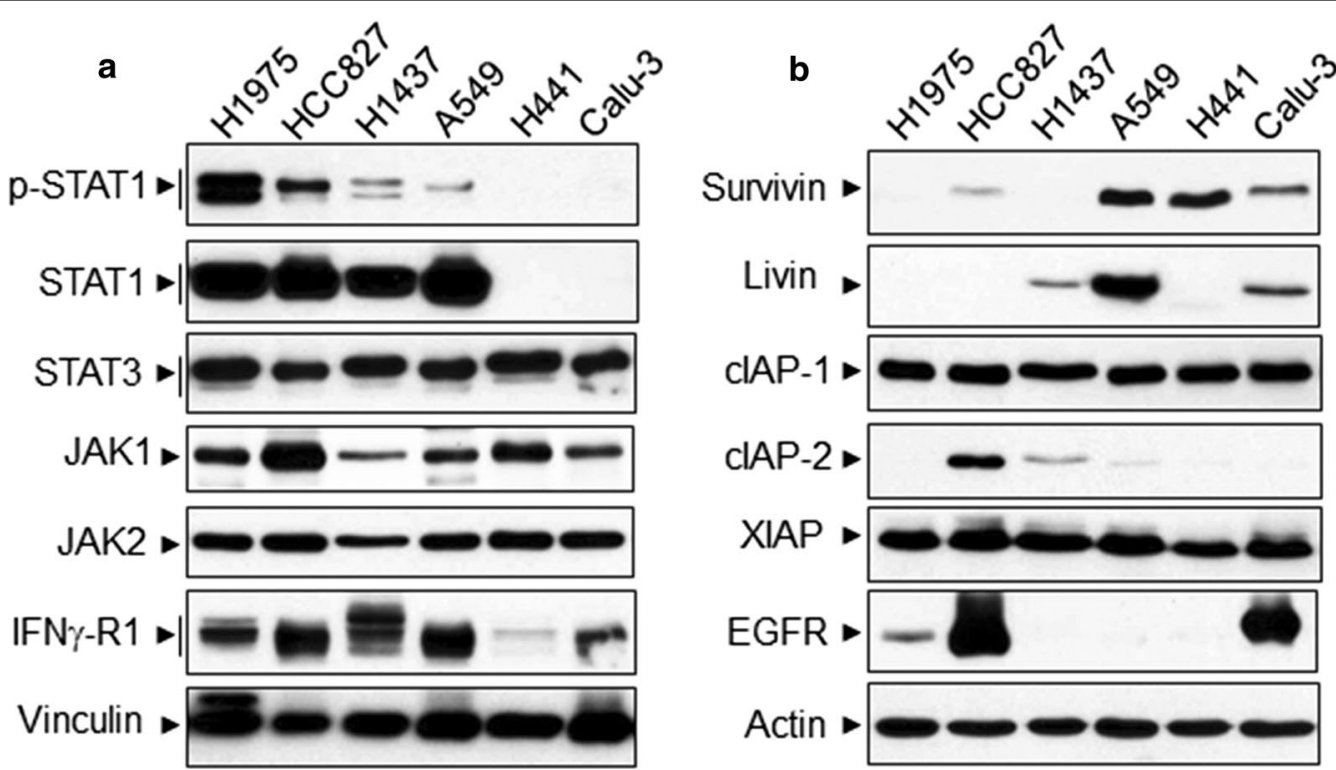

Fig. 7 Expression levels of IFNy signal components and IAP proteins in NSCLC cell lines. Cell lysates at equal amounts from NSCLC cell lines were subjected to Western blotting with indicated antibodies. Results represent Western blots of three independent experiments

mimetic therapy for NSCLC. Moreover, among the examined IAP proteins, we found that survivin and livin were highly expressed in A549 cells. Survivin and livin are recognized targets for cancer therapy, including lung cancer; and silencing survivin or livin increases apoptosis and sensitizes NSCLC cells to chemotherapy [31-33]. This suggests that the high expression levels of survivin and livin in A549 cells may render the cell not very responsive to IFN $\gamma / \mathrm{Smac}$ mimetic regimen and that STAT1 together with survivin and livin may be valuable biomarkers that can predict the optimal responses to IFN $\gamma / \mathrm{Smac}$ mimetic therapy for NSCLC. Importantly, we found that normal human alveolar epithelial cells were resistant to IFN $\gamma / \mathrm{Smac}$ mimetic co-treatment even though IFN $\gamma$ signaling components were expressed in the cells. Hence IFN $\gamma /$ Smac mimetic therapy preferentially targets IFN $\gamma$ signaling competent NSCLC cells but not normal human lung epithelial cells.

Unlike type II IFN $\gamma$, IFN $\alpha$, IFN $\lambda$, TNF $\alpha$, or TRAIL alone or in combination with Smac mimetic AZD5582 had very minor effects on cell viability in the examined NSCLC cell lines. Interestingly, we found that dsRNA poly(I:C) and AZD5582 also synergistically induced apoptosis in H1975 cells but not in other 5 NSCLC cell lines. It has been shown that poly(I:C) also can cooperate with Smac mimetics to kill murine EMT6 breast cancer cells [34]. Poly(I:C) can be recognized by dsRNA receptors, such as endosomal Toll-like receptor 3 and cytosolic RIG1-like receptors including RIG-1,
MDA5, and LGP2. Direct addition of poly(I:C) to culture medium or transfection of poly(I:C) into H1975 cells could cooperate with AZD5582 to trigger apoptosis; and the effects were potentiated by including of IFNy. However, colony formation assay revealed that a great number of colonies still formed by the treatment of AZD5582 alone or AZD5582 plus poly(I:C). In contrast, no cell colony could survive by co-treatment of AZD5582 with IFN $\gamma$ at 1 or $5 \mathrm{ng} / \mathrm{ml}$. Collectively, these findings indicate that IFN $\gamma / \mathrm{Smac}$ mimetic therapy is much stronger and broader than AZD5582/ poly(I:C) co-treatment for killing NSCLC cells. Moreover, the mechanism of AZD5582/IFN $\gamma$-induced apoptosis in H1975 cells appears to be different at some points from AZD5582/poly(I:C) co-treatment. The AZD5582/ IFN $\gamma$-induced apoptosis was dependent on JAK kinase activity and mediated by caspase- 8 and RIPK 1 ; while the AZD5582/poly(I:C)-induced apoptosis was dependent on caspase- 8 and regulated by JAK kinase but not RIPK1. Nevertheless, the apoptosis by AZD5582 plus IFN $\gamma$ or poly(I:C) was not affected by a human TNF $\alpha$ neutralizing antibody, indicating a TNF $\alpha$-independent mechanism. IFN- $\gamma$ has antitumor activity and has been used clinically to treat a variety of malignancies, albeit with mixed results $[15,35]$. As Smac mimetics have been shown to be well-tolerated in early clinical trials $[11,12]$, IFN $\gamma$ and Smac mimetic combination therapy merits further investigation and may present a promising novel apoptosis targeted regimen for a subgroup of lung cancer cells with biomarkers to predict responses. 


\section{Conclusions}

In summary, we have shown that a number of human NSCLC cell lines that are competent for IFNy signaling (i.e. expressing IFNy receptor-1 and STAT1) but have low expression levels of IAP proteins survivin and livin, can be readily killed and eradicated through apoptosis by IFN $\gamma$ and Smac mimetic co-treatment without harming normal human lung epithelial cells.

\section{Abbreviations \\ IFN: interferon; Smac: second mitochondria-derived activator of caspases; NSCLC: non-small cell lung cancer; IAP: inhibitor of apoptosis; EGFR: epidermal growth factor receptor; CIAP: cellular IAP; XIAP: X-linked IAP; TNF: tumor necrosis factor; TRAIL:TNF-related apoptosis-inducing ligand; poly(l:C): polyi- nosinic-polycytidylic acid; RIPK1: receptor-interacting protein kinase 1; PARP: poly(ADP-ribose) polymerase.}

\section{Authors' contributions}

H.T. conceived and designed the study. Q.H. and H.T. performed the experiments and analyzed the data. H.T. wrote the manuscript. All authors read and approved the final manuscript.

\section{Acknowledgements}

We thank Michael Tang for critical reading and edition and Dr. Buka Samten for flow cytometry.

\section{Competing interests}

The authors declare that they have no competing interests.

\section{Availability of data and materials}

The datasets used and/or analysed during the current study are available from the corresponding author on reasonable request.

\section{Consent for publication}

Not applicable.

\section{Ethics approval and consent to participate}

Not applicable.

\section{Funding}

This study was supported in part by an institutional seed grant.

\section{Publisher's Note}

Springer Nature remains neutral with regard to jurisdictional claims in published maps and institutional affiliations.

Received: 26 March 2018 Accepted: 6 June 2018

Published online: 14 June 2018

\section{References}

1. Molina JR, Yang P, Cassivi SD, Schild SE, Adjei AA. Non-small cell lung cancer: epidemiology, risk factors, treatment, and survivorship. Mayo Clin Proc. 2008;83(5):584-94.

2. Petersen I, Petersen S. Towards a genetic-based classification of human lung cancer. Anal Cell Pathol. 2001;22(3):111-21.

3. Siegel R, Naishadham D, Jemal A. Cancer statistics, 2013. CA Cancer J Clin. 2013:63(1):11-30.

4. Wallach D, Kang TB, Dillon CP, Green DR. Programmed necrosis in inflammation: toward identification of the effector molecules. Science. 2016;352(6281):aaf2154.

5. Fulda S, Vucic D. Targeting IAP proteins for therapeutic intervention in cancer. Nat Rev Drug Discov. 2012;11(2):109-24.
6. Fulda S, Galluzzi L, Kroemer G. Targeting mitochondria for cancer therapy. Nat Rev Drug Discov. 2010;9(6):447-64.

7. Greer RM, Peyton M, Larsen JE, Girard L, Xie Y, Gazdar AF, Harran P, Wang L, Brekken RA, Wang X, et al. SMAC mimetic (JP1201) sensitizes non-small cell lung cancers to multiple chemotherapy agents in an IAP-dependent but TNF-alpha-independent manner. Cancer Res. 2011;71(24):7640-8.

8. Yang C, Wang H, Zhang B, Chen Y, Zhang Y, Sun X, Xiao G, Nan K, Ren H, Qin S. LCL161 increases paclitaxel-induced apoptosis by degrading CIAP1 and CIAP2 in NSCLC. J Exp Clin Cancer Res. 2016;35(1):158.

9. Langdon CG, Wiedemann N, Held MA, Mamillapalli R, lyidogan P, Theodosakis N, Platt JT, Levy F, Vuagniaux G, Wang S, et al. SMAC mimetic Debio 1143 synergizes with taxanes, topoisomerase inhibitors and bromodomain inhibitors to impede growth of lung adenocarcinoma cells. Oncotarget. 2015;6(35):37410-25

10. Pore MM, Hiltermann TJ, Kruyt FA. Targeting apoptosis pathways in lung cancer. Cancer Lett. 2013:332(2):359-68.

11. Fulda S. Smac mimetics as IAP antagonists. Semin Cell Dev Biol. 2015;39:132-8.

12. Fulda S. Promises and challenges of Smac mimetics as cancer therapeutics. Clin Cancer Res. 2015:21(22):5030-6.

13. Tang H, Zhao ZJ, Landon EJ, Inagami T. Regulation of calcium-sensitive tyrosine kinase Pyk2 by angiotensin II in endothelial cells. Roles of Yes tyrosine kinase and tyrosine phosphatase SHP-2. J Biol Chem. 2000;275(12):8389-96.

14. Hennessy EJ, Adam A, Aquila BM, Castriotta LM, Cook D, Hattersley M, Hird AW, Huntington C, Kamhi VM, Laing NM, et al. Discovery of a novel class of dimeric Smac mimetics as potent IAP antagonists resulting in a clinical candidate for the treatment of cancer (AZD5582). J Med Chem. 2013:56(24):9897-919.

15. Galani V, Kastamoulas M, Varouktsi A, Lampri E, Mitselou A, Arvanitis DL. IFNs-signaling effects on lung cancer: an up-to-date pathways-specific review. Clin Exp Med. 2017;17(3):281-9.

16. Lu J, Bai L, Sun H, Nikolovska-Coleska Z, McEachern D, Qiu S, Miller RS, Y $H$, Shangary S, Sun Y, et al. SM-164: a novel, bivalent Smac mimetic that induces apoptosis and tumor regression by concurrent removal of the blockade of CIAP-1/2 and XIAP. Cancer Res. 2008;68(22):9384-93.

17. Li W, Li B, Giacalone NJ, Torossian A, Sun Y, Niu K, Lin-Tsai O, Lu B. BV6, an IAP antagonist, activates apoptosis and enhances radiosensitization of non-small cell lung carcinoma in vitro. J Thorac Oncol. 2011;6(11):1801-9.

18. Krepler C, Chunduru SK, Halloran MB, He X, Xiao M, Vultur A, Villanueva J, Mitsuuchi Y, Neiman EM, Benetatos C, et al. The novel SMAC mimetic birinapant exhibits potent activity against human melanoma cells. Clin Cancer Res. 2013;19(7):1784-94.

19. Darding M, Meier P. IAPs: guardians of RIPK1. Cell Death Differ. 2012;19(1):58-66

20. Thompson JE, Cubbon RM, Cummings RT, Wicker LS, Frankshun R, Cunningham BR, Cameron PM, Meinke PT, Liverton N, Weng Y, et al. Photochemical preparation of a pyridone containing tetracycle: a Jak protein kinase inhibitor. Bioorg Med Chem Lett. 2002;12(8):1219-23.

21. Slee EA, Zhu H, Chow SC, MacFarlane M, Nicholson DW, Cohen GM. Benzyloxycarbonyl-Val-Ala-Asp (OMe) fluoromethylketone (Z-VAD.FMK) inhibits apoptosis by blocking the processing of CPP32. Biochem J. 1996:315(Pt 1):21-4.

22. Wang J, Zhen L, Klug MG, Wood D, Wu X, Mizrahi J. Involvement of caspase 3- and 8-like proteases in ceramide-induced apoptosis of cardiomyocytes. J Card Fail. 2000;6(3):243-9.

23. Degterev A, Hitomi J, Germscheid M, Ch'en IL, Korkina O, Teng X, Abbott D, Cuny GD, Yuan C, Wagner G, et al. Identification of RIP1 kinase as a specific cellular target of necrostatins. Nat Chem Biol. 2008;4(5):313-21.

24. Kaiser WJ, Sridharan H, Huang C, Mandal P, Upton JW, Gough PJ, Sehon CA, Marquis RW, Bertin J, Mocarski ES. Toll-like receptor 3-mediated necrosis via TRIF, RIP3, and MLKL. J Biol Chem. 2013;288(43):31268-79.

25. Sun L, Wang H, Wang Z, He S, Chen S, Liao D, Wang L, Yan J, Liu W, Lei X, et al. Mixed lineage kinase domain-like protein mediates necrosis signaling downstream of RIP3 kinase. Cell. 2012;148(1-2):213-27.

26. Wannamaker W, Davies R, Namchuk M, Pollard J, Ford P, Ku G, Decker C, Charifson P, Weber P, Germann UA, et al. (S)-1-((S)-2-\{[1-(4-amino-3chloro-phenyl)-methanoyl]-amino\}-3,3-dimethyl-butanoy I)-pyrrolidine2-carboxylic acid ((2R,3S)-2-ethoxy-5-oxo-tetrahydro-furan-3-yl)-amide (VX-765), an orally available selective interleukin (IL)-converting enzyme/ caspase-1 inhibitor, exhibits potent anti-inflammatory activities by 
inhibiting the release of IL-1 beta and IL-18. J Pharmacol Exp Ther. 2007;321(2):509-16.

27. Dunn GP, Koebel CM, Schreiber RD. Interferons, immunity and cancer immunoediting. Nat Rev Immunol. 2006;6(11):836-48.

28. Vince JE, Wong WW, Khan N, Feltham R, Chau D, Ahmed AU, Benetatos CA, Chunduru SK, Condon SM, McKinlay M, et al. IAP antagonists target CIAP1 to induce TNFalpha-dependent apoptosis. Cell. 2007;131(4):682-93.

29. Petersen SL, Wang L, Yalcin-Chin A, Li L, Peyton M, Minna J, Harran P, Wang $X$. Autocrine TNFalpha signaling renders human cancer cells susceptible to Smac-mimetic-induced apoptosis. Cancer Cell. 2007;12(5):445-56.

30. Chen HY, Yu SL, Chen CH, Chang GC, Chen CY, Yuan A, Cheng CL, Wang $\mathrm{CH}$, Terng HJ, Kao SF, et al. A five-gene signature and clinical outcome in non-small-cell lung cancer. N Engl J Med. 2007;356(1):11-20.

31. Zhao X, Yuan Y, Zhang Z, Feng X, Zhang J, Yuan X, Li J. Effects of shRNAsilenced livin and survivin on lung cancer cell proliferation and apoptosis. J BUON. 2014;19(3):757-62.
32. Zhuang L, Shen LD, Li K, Yang RX, Zhang QY, Chen Y, Gao CL, Dong C, Bi $\mathrm{Q}$, Tao JN, et al. Inhibition of livin expression suppresses cell proliferation and enhances chemosensitivity to cisplatin in human lung adenocarcinoma cells. Mol Med Rep. 2015;12(1):547-52.

33. Chen X, Duan N, Zhang C, Zhang W. Survivin and tumorigenesis: molecular mechanisms and therapeutic strategies. J Cancer. 2016;7(3):314-23.

34. Beug ST, Tang VA, LaCasse EC, Cheung HH, Beauregard CE, Brun J, Nuyens JP, Earl N, St-Jean M, Holbrook J, et al. Smac mimetics and innate immune stimuli synergize to promote tumor death. Nat Biotechnol. 2014;32(2):182-90.

35. Miller $\mathrm{CH}$, Maher SG, Young HA. Clinical use of interferon-gamma. Ann N Y Acad Sci. 2009;1182:69-79.
Ready to submit your research? Choose BMC and benefit from:

- fast, convenient online submission

- thorough peer review by experienced researchers in your field

- rapid publication on acceptance

- support for research data, including large and complex data types

- gold Open Access which fosters wider collaboration and increased citations

- maximum visibility for your research: over 100M website views per year

At BMC, research is always in progress.

Learn more biomedcentral.com/submissions 